\title{
Systematic Review \\ Performance of Copeptin for Early Diagnosis of Acute Coronary Syndromes: A Systematic Review and Meta-Analysis of 14,139 Patients
}

\author{
Lukasz Szarpak 1,2,3,*iD, Marcin Lapinski ${ }^{4}$, Aleksandra Gasecka ${ }^{4,5}$, Michal Pruc ${ }^{3}$ (D), Wiktoria L. Drela ${ }^{6}$ (D), \\ Mariusz Koda $^{2}{ }^{(D}$, Andrea Denegri ${ }^{7}$, Frank W. Peacock ${ }^{8}{ }^{(D}$, Miłosz J. Jaguszewski ${ }^{9}$ and Krzysztof J. Filipiak ${ }^{10}$
}

\section{check for}

Citation: Szarpak, L.; Lapinski, M. Gasecka, A.; Pruc, M.; Drela, W.L.; Koda, M.; Denegri, A.; Peacock, F.W.; Jaguszewski, M.J.; Filipiak, K.J. Performance of Copeptin for Early Diagnosis of Acute Coronary Syndromes: A Systematic Review and Meta-Analysis of 14,139 Patients. J. Cardiovasc. Dev. Dis. 2022, 9, 6. https://doi.org/10.3390/jcdd9010006

Academic Editor: John A. Baugh

Received: 12 November 2021

Accepted: 23 December 2021

Published: 27 December 2021

Publisher's Note: MDPI stays neutral with regard to jurisdictional claims in published maps and institutional affiliations.

Copyright: (c) 2021 by the authors Licensee MDPI, Basel, Switzerland. This article is an open access article distributed under the terms and conditions of the Creative Commons Attribution (CC BY) license (https:// creativecommons.org/licenses/by/ $4.0 /)$.
1 Institute of Outcomes Research, Maria Sklodowska-Curie Medical Academy, 03-411 Warsaw, Poland

2 Research Unit, Maria Sklodowska-Curie Bialystok Oncology Center, 15-027 Bialystok, Poland; kodamar2@gmail.com

3 Research Unit, Polish Society of Disaster Medicine, 05-806 Warsaw, Poland; m.pruc@ptmk.org

4 1st Chair and Department of Cardiology, Medical University of Warsaw, 02-097 Warsaw, Poland; s071447@student.wum.edu.pl (M.L.), gaseckaa@gmail.com (A.G.)

5 Laboratory of Experimental Clinical Chemistry, Amsterdam University Medical Center, 1105 Amsterdam, The Netherlands

6 Students Research Club, Maria Sklodowska-Curie Medical Academy, 04-311 Warsaw, Poland; drelawiktorialaura@gmail.com

7 Cardiology Division, Department of Biomedical, Metabolic and Neural Sciences, University of Modena and Reggio Emilia, Policlinico di Modena, 41121 Modena, Italy; denegri.andrea@aou.mo.it

8 Henry JN Taub Department of Emergency Medicine, Baylor College of Medicine, Houston, TX 77030, USA; frankpeacock@gmail.com

9 1st Department of Cardiology, Medical University of Gdansk, 80-211 Gdansk, Poland; jamilosz@gmail.com

10 Institute of Clinical Medicine, Maria Sklodowska-Curie Medical Academy, 00-001 Warsaw, Poland; krzysztof.filipiak@uczelniamedyczna.com.pl

* Correspondence: Lukasz.szarpak@uczelniamedyczna.com.pl or Lukasz.szarpak@gmail.com; Tel.: +48-500-186-225

Abstract: Diagnosis of acute coronary syndrome (ACS) based on copeptin level may enable one to confirm or rule-out acute myocardial infarction (AMI) with higher sensitivity and specificity, which may in turn further reduce mortality rate and decrease the economic costs of ACS treatment. We conducted a systematic review and meta-analysis to investigate the relationship between copeptin levels and type of ACS. We searched Scopus, PubMed, Web of Science, Embase, and Cochrane to locate all articles published up to 10 October 2021. We evaluated a meta-analysis with random-effects models to evaluate differences in copeptin levels. A total of 14,139 patients (4565 with ACS) were included from twenty-seven studies. Copeptin levels in AMI and non-AMI groups varied and amounted to $68.7 \pm 74.7$ versus $14.8 \pm 19.9 \mathrm{pmol} / \mathrm{L}(\mathrm{SMD}=2.63 ; 95 \% \mathrm{CI}: 2.02$ to $3.24 ; p<0.001)$. Copeptin levels in the AMI group was higher than in the unstable angina (UAP) group, at $51.9 \pm 52.5$ versus $12.8 \pm 19.7 \mathrm{pmol} / \mathrm{L}(\mathrm{SMD}=1.53 ; 95 \% \mathrm{CI}$ : 0.86 to $2.20 ; p<0.001)$. Copeptin levels in STelevation myocardial infarction (STEMI) versus non-ST elevation myocardial infarction (NSTEMI) patient groups were $54.8 \pm 53.0$ versus $28.7 \pm 46.8 \mathrm{pmol} / \mathrm{L}$, respectively $(\mathrm{SMD}=1.69 ; 95 \% \mathrm{CI}:=0.70$ to $4.09 ; p=0.17)$. In summary, elevated copeptin levels were observed in patients with ACS compared with patients without ACS. Given its clinical value, copeptin levels may be included in the assessment of patients with ACS as well as for the initial differentiation of ACS.

Keywords: copeptin; biomarker; acute coronary syndrome; acute myocardial infarction; systematic review

\section{Introduction}

Acute coronary syndromes (ACS) represent the leading cause of morbidity and mortality worldwide [1] and although the relative incidences of ST-elevation myocardial infarction (STEMI) and non-ST elevation myocardial infarction (NSTEMI) are decreasing 
and increasing, respectively [2,3], they are still responsible for almost 1.8 million annual deaths [4]. Instant diagnostics, rapid and accurate assessment of electrocardiographic (ECG) parameters, and troponin are crucial in the identification of patients suffering from acute myocardial infarction (AMI) [3,4]. Distinguishing those requiring immediate intervention and hospitalization is a vital issue both for patients and clinicians [5].

According to current guidelines, besides ECG, cardiac biomarkers and in particular troponins are also used to diagnose AMI [6,7]. However, ruling out AMI with ECG and troponins is time-consuming owing to the need for serial blood sampling to determine the changes in troponin concentrations, especially in patients with non-ST-elevation ACS. The release of high-sensitivity cardiac troponin $\mathrm{T}$ (hs-cTnT) is delayed in comparison with myocardial necrosis onset [8]. Troponin is very sensitive, which leads to a high number of false-positive results $[9,10]$. Therefore, a more reliable indicator of AMI is needed to identify patients who require treatment at an early stage.

Recent studies reported that the level of copeptin, the C-terminal part of argininevasopressin (AVP), may be elevated within $30 \mathrm{~min}$ after the onset of chest pain in patients with AMI [11,12] as a result of endogenous stress response [13]. Copeptin does not require serial sampling, in contrast to troponin [14] and may represent an accurate anchor point to diagnose AMI in patients admitted to ED. Hence, diagnosis of AMI based on copeptin level may enable to confirm or rule-out ACS with higher sensitivity and specificity, which may in turn further reduce mortality rate and decrease the economic costs of AMI treatment. The aim of our meta-analysis was to evaluate the diagnostic value of copeptin in ACS.

\section{Materials and Methods}

This systematic review and meta-analysis follows the recommendation of the Preferred Reporting Items for Systematic Review and Meta-Analyses (PRISMA) statement [15]. Before commencing the study, all authors agreed on the analysis methods and the inclusion and exclusion criteria to be used.

\subsection{Search Strategy}

We search evidence up to 10 October 2021 in the following databases: Scopus, PubMed, Web of Science, Embase, and Cochrane. The search was conducted using the following terms: "copeptin" OR "copeptins" OR "Glycopeptides" OR "Glycopeptide" OR “Cterminal provasopressin" AND "acute myocardial infarction" OR "AMI" OR "myocardial infarction" OR "MI" OR “STEMI" OR "ST-Elevation" OR "non-ST segment elevation" OR "NSTEMI" OR "ACS" OR "acute coronary syndrome". All references were saved in an EndNote (End Note, Inc, Philadelphia, PA) library used to identify the duplicates. We did not limit the search by language or publication date. We also manually searched the reference list of identified trials for other potentially eligible studies.

\subsection{Inclusion Criteria}

Studies included in this meta-analysis met the following PICOS criteria: (1) PARTICIPANTS, patients > 18 years of age; (2) INTERVENTION, patients with AMI; (3) COMPARISON, patients without AMI; (4) OUTCOMES, detailed information for copeptin levels; and (5) STUDY DESIGN, randomized controlled trials or observational studies comparing copeptin levels in patients with and without AMI or comparing copeptin levels in patients with different AMI groups.

This review excluded the following types of studies: (1) papers not containing a comparator group; (2) conference or poster papers; (3) reviews; (4) case reports; and (5) articles not containing original data.

\subsection{Data Extraction}

Two authors (L.S. and S.B.) independently reviewed the selected trials and extracted the data of interest. The extraction of data was performed using a pre-piloted Microsoft Excel sheet. We were careful to avoid including data from duplicate publications. In the 
case of suspected data discrepancies, we contacted the relevant corresponding author directly. Data extracted from eligible trials included the following parameters: (1) study characteristics (i.e., first author's name, year of publication, study location, study design, inclusion and exclusion criteria, and primary findings); (2) participant characteristics in each group (i.e., number of participants, age, sex, comorbidities, and copeptin levels). All detailed information was checked by a third author (L.K.), with disagreements resolved by discussion and consensus.

\subsection{Quality Assessment}

A systematic assessment of bias in the included studies was performed using the Cochrane criteria [16,17]. For this purpose, a tool for Risk Of Bias In Non-randomized Studies-of Interventions (ROBINS-I) [18] was used. ROBINS-I examines seven domains of bias owing to the following: (1) confounding; (2) selection of participants; (3) the classification of interventions; (4) deviations from intended interventions; (5) missing data; (6) measurement of outcomes; and (7) the selection of the reported result. The overall ROBINS-I judgment at domain and study level was attributed to the criteria specified in the ROBVIS tool [19]. The risk of bias (RoB) was performed independently by three reviewers (A.G., L.K., and M.L.); disagreements were resolved by a third reviewer (L.S.) if necessary.

\subsection{Statistical Analysis}

All analyses were performed using Cochranre Review Manager (ver. 5.4, Nordic Cochrane Centre, The Cochrane Collaboration, Copenhagen, Denmark). The MantelHaenszel method was used to analyze dichotomous outcomes, and results are reported as odds ratios (ORs) or risk ratios (RRs) with a 95\% confidence interval (CI). Continuous outcome differences were analyzed using an inverse variance model with a $95 \% \mathrm{CI}$, and values are reported as mean difference (MD). When the continuous outcome was reported in a study as median, range, and interquartile range, we estimated means and standard deviations using the formula described by Hozo et al. [16].

We quantified heterogeneity in each analysis by the tau-squared and I-squared statistics. Heterogeneity was detected with the chi-squared test with $n-1$ degree of freedom, which was expressed as $\mathrm{I}^{2}$. Values of $\mathrm{I}^{2}>50 \%$ and $>75 \%$ were considered to indicate moderate and significant heterogeneity among studies, respectively. A random-effects model was used to pool study results independently of the $p$-value for heterogeneity or $\mathrm{I}^{2}$ [17]. All $p$-values were two-tailed and considered significant if $<0.05$.

To evaluate the potential for publication bias, we plotted values against associated standard errors [18] and used Begg's test to assess the symmetry of the resulting funnel plot [19]. We considered publication bias to be present when the $p$-value was $<0.1$ in the asymmetry test. However, when a limited number of studies $(<10)$ were included in the analysis, publication bias was not evaluated.

\section{Results}

\subsection{Study Selection}

Figure 1 shows the results of the search and article selection. The final set consisted of 27 eligible studies [20-46], including 6 articles conducted in Germany [23,32,34,39,40,42]; 5 articles in France [25,26,31,37,41]; 2 articles in Switzerland [36,45]; 2 articles in Egypt [20,27]; 1 from each of the following countries: Denmark [46], Iceland [44], Korea [33], USA [35], Poland [38], Sweden [43], Spain [21], The Netherlands [29], and Turkey [22]; and 2 international articles $[24,28]$. The total number of participants was 14,139. All of those studies focused on the copeptin levels in acute coronary syndrome. 


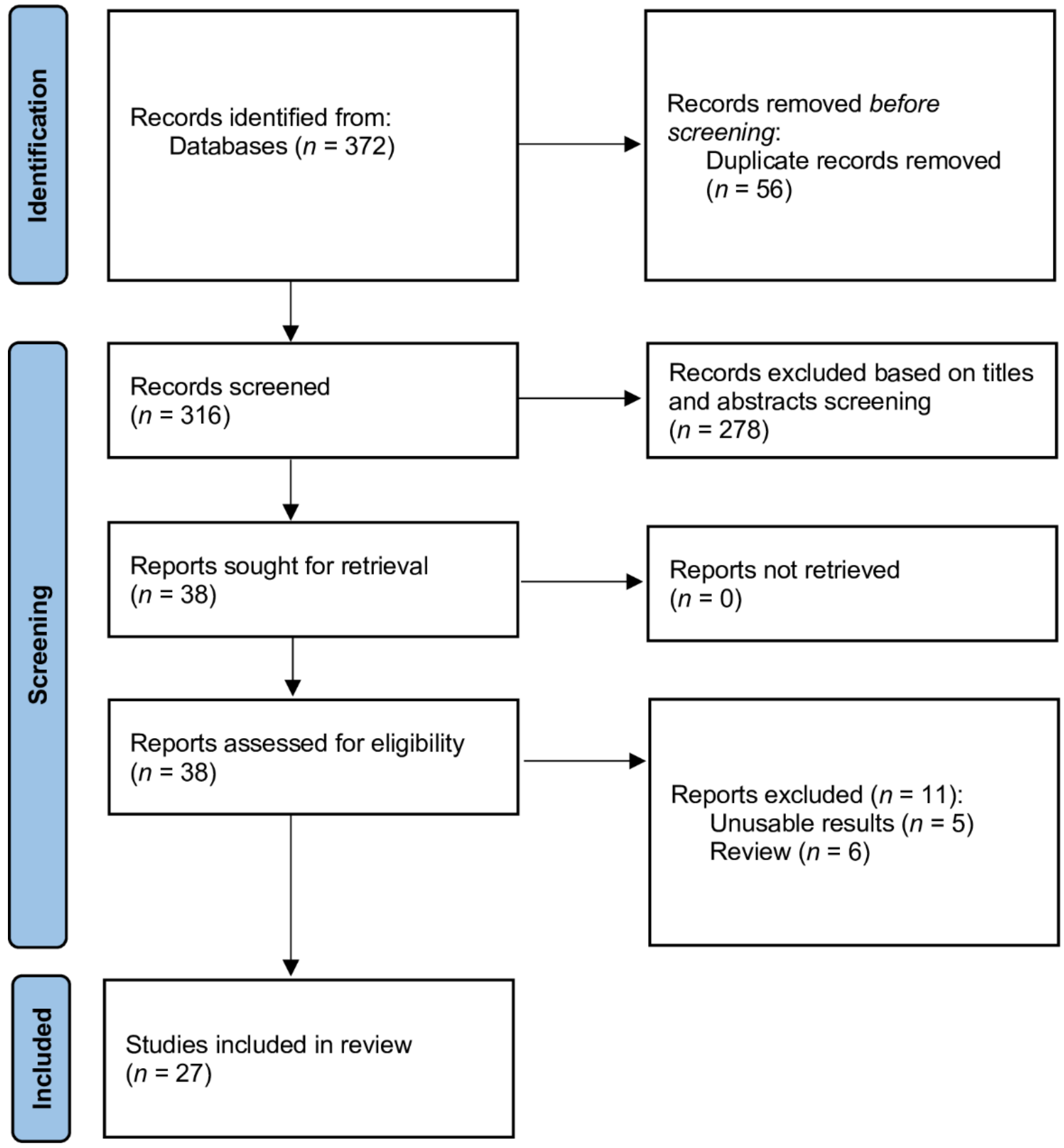

Figure 1. Flow diagram showing stages of the database search and study selection as per Preferred Reporting Items for Systematic Reviews and Meta-Analyses (PRISMA) guidelines.

Among the included trials, the mean age of patients with and without ACS varied and amounted to $66.1 \pm 10.4$ versus $62.2 \pm 12.7$ years, respectively. Males accounted for $71.5 \%$ of patients in the ACS group compared with 59.3\% in the patients without ACS group. The details of the included studies are summarized in Table 1 and Table S1. 
Table 1. Characteristics of included studies. Legend: NR = not reported.

\begin{tabular}{|c|c|c|c|c|c|c|c|c|}
\hline \multirow{2}{*}{ Study } & \multirow{2}{*}{ Country } & \multirow{2}{*}{ Study Design } & \multicolumn{3}{|c|}{ ACS Group } & \multicolumn{3}{|c|}{ No-ACS Group } \\
\hline & & & No. & Age & Sex, Male & No. & Age & Sex, Male \\
\hline $\begin{array}{l}\text { Ahmed et al., } \\
2021\end{array}$ & Egypt & Prospective observational follow-up study & 79 & $58.31 \pm 9.61$ & $44(69.6 \%)$ & NR & NR & NR \\
\hline $\begin{array}{l}\text { Alqueézar } \\
\text { et al., } 2017\end{array}$ & Spain & Retrospective observational study & 63 & $72.3 \pm 4.3$ & $45(71.4 \%)$ & 234 & $67.3 \pm 2.5$ & $154(88.8 \%)$ \\
\hline Ay et al., 2017 & Turkey & Retrospective observational study & 108 & $59.8 \pm 10.3$ & $80(74.1 \%)$ & 52 & $55.3 \pm 12.6$ & $30(57.7 \%)$ \\
\hline $\begin{array}{l}\text { Bahrmann } \\
\text { et al., } 2013\end{array}$ & Germany & Retrospective observational study & 38 & $82 \pm 6$ & $23(60.5 \%)$ & 268 & $80 \pm 6$ & $126(47.1 \%)$ \\
\hline $\begin{array}{l}\text { Boeddinghaus } \\
\text { et al., } 2017\end{array}$ & International & Prospective internationalmulticenter study & 39 & $73.5 \pm 4.6$ & $31(79.5 \%)$ & 41 & $72.3 \pm 6.1$ & $28(68.3 \%)$ \\
\hline $\begin{array}{l}\text { Charpentier } \\
\text { et al., } 2012\end{array}$ & France & Prospectivesingle-center study & 95 & $67 \pm 15.6$ & $66(69.5 \%)$ & 546 & $56 \pm 16.2$ & $358(65.6 \%)$ \\
\hline $\begin{array}{l}\text { Duchenne } \\
\text { et al., } 2014\end{array}$ & France & $\begin{array}{l}\text { Prospective internationalmulticenter } \\
\text { cohort study }\end{array}$ & 8 & $66 \pm 16$ & $7(87.5 \%)$ & 94 & $57 \pm 55.9$ & $57(55.9 \%)$ \\
\hline $\begin{array}{c}\text { Gaber et al., } \\
2021\end{array}$ & Egypt & Prospective case-controlled study & 65 & $61 \pm 9.8$ & $35(53.8 \%)$ & 25 & $56.9 \pm 15.7$ & $13(52.0 \%)$ \\
\hline $\begin{array}{l}\text { Hillinger et al., } \\
2015 \\
\end{array}$ & International & Prospective internationalmulticenter study & 267 & $72 \pm 3.3$ & $191(71.5 \%)$ & 1172 & $61.3 \pm 4.2$ & $795(67.8 \%)$ \\
\hline $\begin{array}{l}\text { Jacobs et al., } \\
2015\end{array}$ & $\begin{array}{l}\text { The } \\
\text { Nether- } \\
\text { lands }\end{array}$ & Retrospective observational study & 141 & $65.8 \pm 3.5$ & $107(75.9 \%)$ & 443 & $61 \pm 3.7$ & $246(55.5 \%)$ \\
\hline $\begin{array}{l}\text { Jeong et al., } \\
2020\end{array}$ & Korea & Prospectivesingle-center study & 146 & $62.2 \pm 6.5$ & $110(75.3 \%)$ & 125 & $56.7 \pm 2.4$ & $77(61.6 \%)$ \\
\hline $\begin{array}{l}\text { Keller et al., } \\
2010\end{array}$ & France & Prospectivemulticenter study & 483 & $64.7 \pm 10.9$ & $351(72.7 \%)$ & 903 & $59.8 \pm 14.3$ & $569(63.0 \%)$ \\
\hline $\begin{array}{l}\text { Khan et al., } \\
\quad 2007\end{array}$ & Germany & Prospectivesingle-center study & 980 & $62.8 \pm 11.8$ & $718(73.3 \%)$ & 700 & $61.9 \pm 5.9$ & $409(58.4 \%)$ \\
\hline $\begin{array}{l}\text { Kim et al., } \\
2020\end{array}$ & Korea & Prospective observational study & 28 & $67.9 \pm 5.1$ & $21(75.0 \%)$ & 235 & $66 \pm 3.0$ & $131(55.7 \%)$ \\
\hline $\begin{array}{l}\text { Lotze et al., } \\
2011\end{array}$ & Germany & Prospective observational study & 13 & $64.5 \pm 11.2$ & $11(84.6 \%)$ & 129 & $71.8 \pm 13.6$ & $65(50.4 \%)$ \\
\hline $\begin{array}{l}\text { Maisel et al., } \\
2013\end{array}$ & USA & Prospectivemulticenter study & 156 & $61.6 \pm 11.4$ & $117(75.0 \%)$ & 1811 & $56 \pm 12.8$ & $1001(55.3 \%)$ \\
\hline $\begin{array}{l}\text { Mauermann } \\
\text { et al., } 2016\end{array}$ & Switzerland & $\begin{array}{l}\text { Secondary analysis of prospectively } \\
\text { collected data }\end{array}$ & 33 & $74 \pm 6$ & $30(90.9 \%)$ & 157 & $72 \pm 8$ & $115(73.2 \%)$ \\
\hline $\begin{array}{l}\text { Meune et al., } \\
2011\end{array}$ & France & Prospective cohort study & 30 & $61.8 \pm 13.6$ & $22(73.3 \%)$ & 28 & $53.7 \pm 12.3$ & $15(53.6 \%)$ \\
\hline $\begin{array}{l}\text { Morawiec } \\
\text { et al., } 2018\end{array}$ & Poland & Cohort, cross-sectional study & 105 & $64 \pm 2.7$ & $73(69.5 \%)$ & 49 & $62 \pm 4.0$ & $27(55.1 \%)$ \\
\hline $\begin{array}{l}\text { Narayan et al., } \\
2011\end{array}$ & Germany & Prospective cohort study & 754 & $68.5 \pm 10$ & $519(68.8 \%)$ & 123 & $72.3 \pm 2.7$ & $82(66.7 \%)$ \\
\hline $\begin{array}{l}\text { Reichlin et al., } \\
2009\end{array}$ & Germany & Prospective cohort study & 81 & $68 \pm 15$ & $58(71.8 \%)$ & 406 & $61 \pm 17$ & $263(64.8 \%)$ \\
\hline $\begin{array}{l}\text { Sebbane et al., } \\
2013\end{array}$ & France & Prospective cohort study & 52 & $60.4 \pm 7.0$ & $32(60.8 \%)$ & NR & NR & NR \\
\hline $\begin{array}{l}\text { Slagman et al., } \\
2015\end{array}$ & Germany & Prospective cohort study & 77 & $56.7 \pm 5.8$ & $65(84.4 \%)$ & 16 & $58.5 \pm 5.2$ & $11(68.8 \%)$ \\
\hline $\begin{array}{l}\text { Smaradottir } \\
\text { et al., } 2017\end{array}$ & Sweden & Prospective cohort study & 166 & $64 \pm 2.3$ & $116(69.9 \%)$ & 168 & $64.5 \pm 2.3$ & $115(68.5 \%)$ \\
\hline $\begin{array}{l}\text { Smaradottir } \\
\text { et al., } 2021\end{array}$ & Iceland & Retrospective cohort study & 246 & $77.5 \pm 1.3$ & $157(63.8 \%)$ & 680 & $76 \pm 1.3$ & $292(42.9 \%)$ \\
\hline $\begin{array}{l}\text { Stallone et al., } \\
2016\end{array}$ & Switzerland & Prospective cohort study & 102 & $67.3 \pm 3.5$ & $76(74.5 \%)$ & 417 & $57.5 \pm 4.0$ & $284(68.1 \%)$ \\
\hline $\begin{array}{l}\text { Stengaard } \\
\text { et al., } 2016\end{array}$ & Denmark & Retrospective study & 210 & $69 \pm 2.6$ & $160(76.2 \%)$ & 752 & $65.1 \pm 0.4$ & $417(55.4 \%)$ \\
\hline
\end{tabular}

\subsection{Results of the Meta-Analysis}

The pooled analysis of twenty-six studies showed that copeptin levels in AMI and nonAMI groups varied and amounted to $68.7 \pm 74.7$ versus $14.8 \pm 19.9 \mathrm{pmol} / \mathrm{L}(\mathrm{SMD}=2.63$; 95\% CI: 2.02 to $3.24 ; \mathrm{I}^{2}=99 \% ; p<0.001$ ) [21-35,37-46]. Subanalysis by type of AMI showed that higher concentrations of copeptin in the AMI group versus no-AMIs group were 
reported across all subgroups: STEMI $(82.5 \pm 95.9$ vs. $7.9 \pm 4.5 \mathrm{pmol} / \mathrm{L}$, respectively; $\mathrm{SMD}=3.94 ; 95 \%$ CI: 1.87 to $6.01 ; \mathrm{I}^{2}=96 \% ; p<0.001$; Figure 2$)$, NSTEMI (100.8 \pm 89.4 vs. $11.1 \pm 8.4 \mathrm{pmol} / \mathrm{L} ; \mathrm{SMD}=2.40 ; 95 \% \mathrm{CI}: 1.31$ to $\left.3.49 ; \mathrm{I}^{2}=99 \% ; p<0.001\right)$, as well as in the unspecified AMI group (56.3 \pm 62.2 vs. $15.5 \pm 21.5 \mathrm{pmol} / \mathrm{L} ; \mathrm{SMD}=2.86 ; 95 \% \mathrm{CI}: 2.06$ to $\left.3.66 ; \mathrm{I}^{2}=99 \% ; p<0.001\right)$.

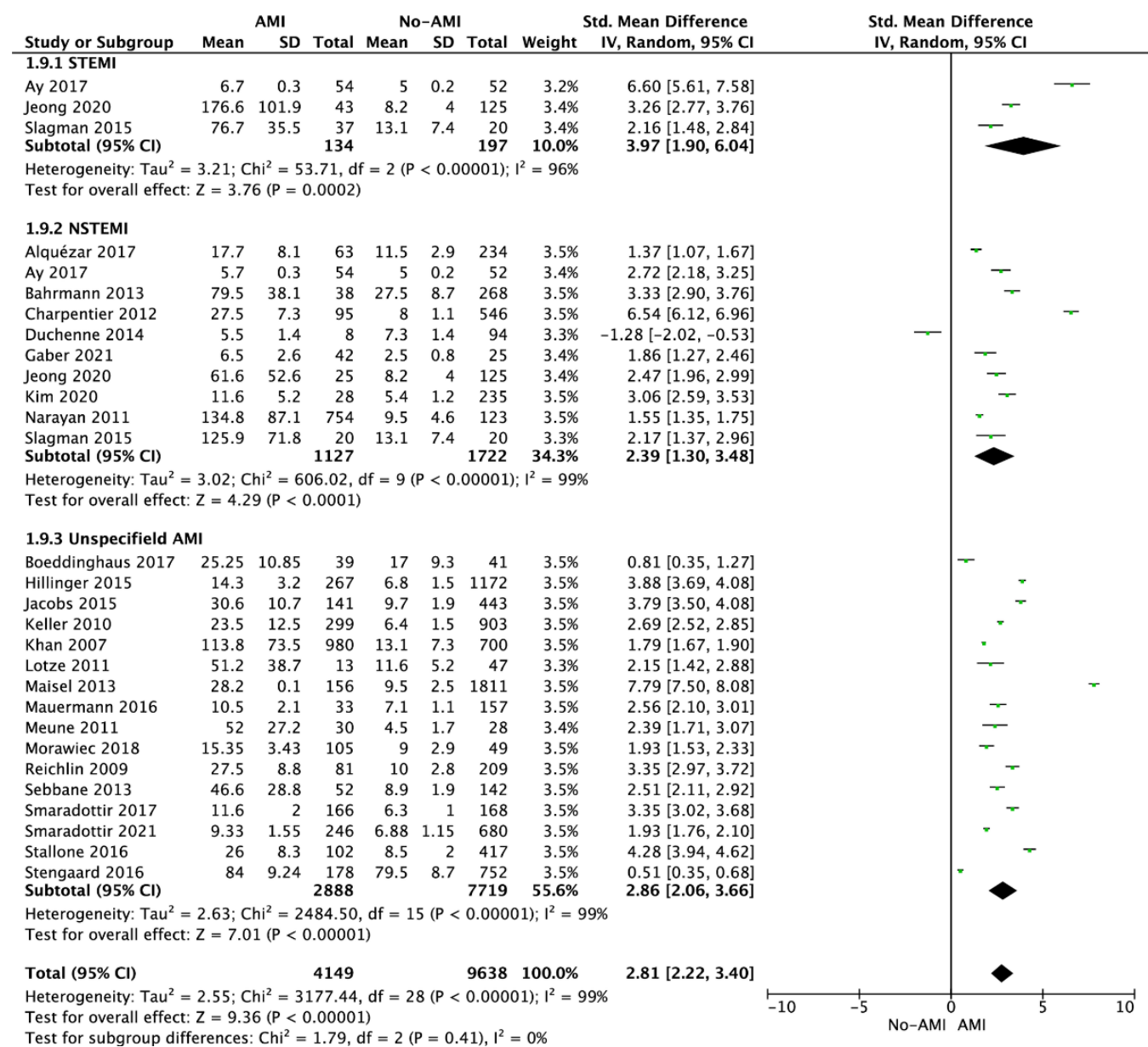

Figure 2. Forest plot of copeptin levels in the AMI and no-AMI groups. The center of each square represents the weighted standard mean difference for individual trials, and the corresponding horizontal line stands for a $95 \%$ confidence interval. The diamonds represent pooled results. Legend: $\mathrm{CI}=$ confidence interval; SMD = standard mean difference.

Eight studies reported copeptin levels between AMI and unstable angina pectoris (UAP) groups $[20,27,30,31,34,40,42,46]$. Pooled analysis showed that mean copeptin levels in the AMI group were higher than in the UAP group $51.9 \pm 52.5 \mathrm{pmol} / \mathrm{L} ; 12.8 \pm 19.7 \mathrm{pmol} / \mathrm{L}$ $\left(\mathrm{SMD}=1.53 ; 95 \%\right.$ CI: 0.86 to $\left.2.20 ; \mathrm{I}^{2}=95 \% ; p<0.001\right)$. Subanalysis showed that copeptin levels were higher in the AMI group compared with the UAP group across all subgroups: STEMI (128.2 \pm 91.7 vs. $11.7 \pm 4.8 \mathrm{pmol} / \mathrm{L}$ respectively; $\mathrm{SMD}=2.46 ; 95 \% \mathrm{CI}: 2.00$ to 2.92; $p<0.001)$, NSTEMI (41.5 \pm 58.9 vs. $8.8 \pm 5.6$ pmol $/ \mathrm{L} ; \mathrm{SMD}=1.76 ; 95 \% \mathrm{CI}: 1.34$ to 2.18; $\left.\mathrm{I}^{2}=51 \% ; p<0.001\right)$, and unspecified AMI (43.6 \pm 30.1 vs. $15.2 \pm 24.5 \mathrm{pmol} / \mathrm{L} ; \mathrm{SMD}=1.45 ;$ $95 \%$ CI: 0.07 to $2.82 ; \mathrm{I}^{2}=98 \% ; p=0.04$; Figure 3 ). 


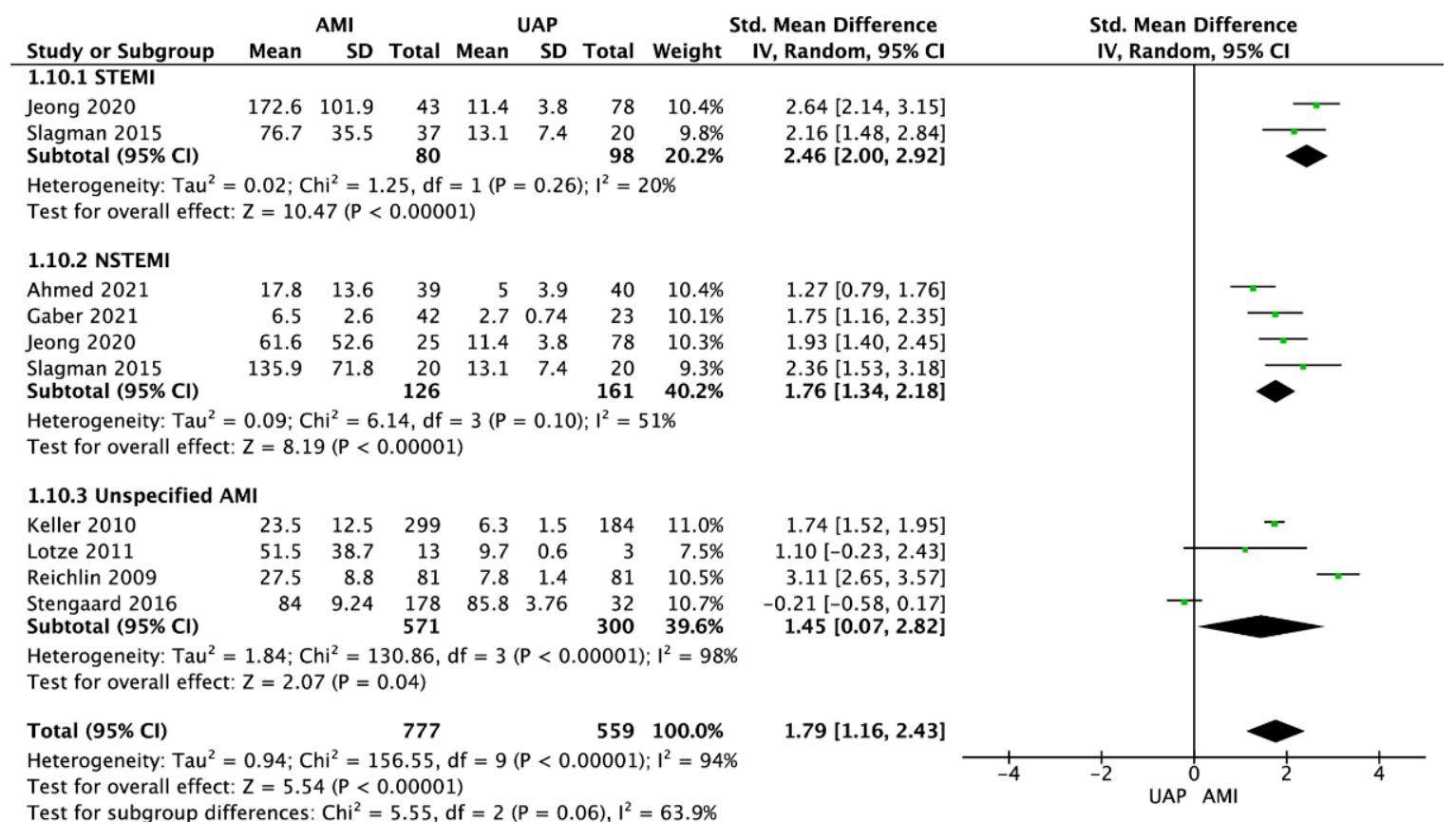

Figure 3. Forest plot of copeptin levels in the AMI and UAP groups. The center of each square represents the weighted standard mean difference for individual trials, and the corresponding horizontal line stands for a $95 \%$ confidence interval. The diamonds represent pooled results. Legend: $\mathrm{CI}=$ confidence interval; $\mathrm{SMD}=$ standard mean difference.

Three studies $[22,29,42]$ reported copeptin levels in STEMI versus NSTEMI patient groups, which were $54.8 \pm 53.0$ versus $28.7 \pm 46.8 \mathrm{pmol} / \mathrm{L}(\mathrm{SMD}=1.69 ; 95 \% \mathrm{CI}:=0.70$ to $4.09 ; \mathrm{I}^{2}=98 \% ; p=0.17$; Figure 4).

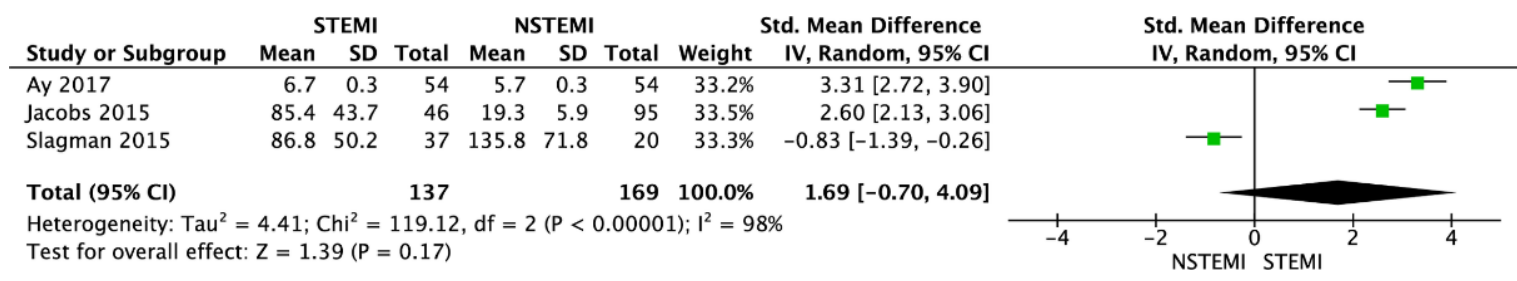

Figure 4. Forest plot of copeptin levels in the STEMI and NSTEMI groups. The center of each square represents the weighted standard mean difference for individual trials, and the corresponding horizontal line stands for a $95 \%$ confidence interval. The diamonds represent pooled results. Legend: $\mathrm{CI}=$ confidence interval; $\mathrm{SMD}=$ standard mean difference.

\section{Discussion}

According to our study, copeptin assessment is a strong diagnostic tool in patients with AMI thanks to its high negative predictive value (NPV). Ruling out healthy individuals reporting at least chest pain may increase the efficacy of work in the emergency department. However, it was found that a combination of copeptin and hs-cTnT is even more sensitive to rule out NSTEMI, compared with both of those markers tested independently [41]. It was also shown that the double-testing approach has an excellent NPV for short-term risk stratification, and such a strategy is able to improve a triage system in an emergency department. Other authors also showed that copeptin measurement alone exhibits inferior results towards its combination with either N-terminal pro b-type natriuretic peptide (NT-proBNP) or troponin. Although, according to the latest ESC Guidelines, routine measurement of additional biomarkers for diagnostic purposes is not recommended, and assessment of copeptin may add a substantial value to (less sensitive) cardiac troponin [31,47]. Copeptin 
could be used as a marker to diagnose AMI, but so far, further studies are required to evaluate its potential superiority over the currently available markers of AMI.

In addition to the diagnostic role of copeptin, it acts as a mortality predictor after AMI. In an analysis of 926 patients with AMI, a significant association between the copeptin level and the risk of mortality was found, independently from cortisol and NT-proBNP measurements [44].

Three studies reported a higher level of copeptin in patients with the STEMI compared with the NSTEMI group. That may suggest a positive correlation of copeptin serum concentration with AMI severity. Moreover, the lack of necessity of serial blood sampling is highlighted by some authors [48]. Not only would it reduce the total cost of diagnostic procedures, but also it enables to obviate prolonged monitoring and thus improve the pace of medical care service. Copeptin has been demonstrated to present an acceptable prognostic value for mortality in patients with ACS, but this finding has to be confirmed in a larger multi-marker strategy to evaluate the prognostic value of copeptin for ACS in conjunction and comparison with other well-established biomarkers [44,49].

However, there are some data undermining copeptin utility in the diagnostic path. In some research, it was proved that copeptin measurement substantially does not improve the early diagnosis of AMI and, referring to another study, its accuracy was moderate and inferior to that of hs-cTnT $[24,45]$.

We acknowledge some limitations of our study. Firstly, because of significant heterogeneity of gathered data, it is hard to determine whether the "non-AMI" group was formed by patients suffering from unstable angina, people reporting chest pain at the admission, or healthy individuals. Secondly, the cut-offs for elevated copeptin concentrations differed per study. Therefore, the value of copeptin level in this cohort may be debatable. On this account, it is hard to determine the role of diagnostic and prognostic role of copeptin in AMI. Whereas it seems to be a useful tool, too few data are currently available to classify it as a standard of care, self-sufficient biomarker of AMI. Thereby, further multicenter randomized control trials should be conducted to draw final conclusions.

\section{Conclusions}

Elevated copeptin levels were observed in patients with ACS compared with patients without ACS. Given its clinical value, copeptin levels may be included in the assessment of patients with ACS as well as for the initial differentiation of ACS.

Supplementary Materials: The following are available online at https:/ / www.mdpi.com/article / 10.3390/jcdd9010006/s1; Table S1: Methodology characteristics of included studies; Figure S1: A summary table of review authors' judgements for each risk of bias item for each study; Figure S2: A plot of the distribution of review authors' judgements across studies for each risk of bias item.

Author Contributions: Conceptualization, L.S.; methodology, L.S. and F.W.P.; software, L.S.; validation, M.J.J. and K.J.F.; formal analysis, L.S.; investigation, L.S., M.P., M.L, A.G., and M.K.; resources, L.S. and A.G.; data curation, M.P. and M.L.; writing-original draft preparation, L.S., A.G., and M.L.; writing—review and editing, L.S., M.L., A.G., M.P., W.L.D., M.K., A.D., F.W.P., M.J.J., K.J.F.; visualization, L.S.; supervision, L.S. and M.J.J.; project administration, L.S.; funding acquisition, L.S. All authors have read and agreed to the published version of the manuscript.

Funding: This research received no external funding.

Institutional Review Board Statement: Not applicable.

Informed Consent Statement: Not applicable.

Data Availability Statement: Not applicable.

Acknowledgments: The study was supported by the Polish Society of Disaster Medicine.

Conflicts of Interest: The authors declare no conflict of interest. 


\section{References}

1. Lüscher, T.F. Outcomes of acute coronary syndromes: Clinical presentation, gender, inflammation, and cell therapy. Eur. Heart J. 2017, 38, 125-129. [CrossRef]

2. Sugiyama, T.; Hasegawa, K.; Kobayashi, Y.; Takahashi, O.; Fukui, T.; Tsugawa, Y. Differential time trends of outcomes and costs of care for acute myocardial infarction hospitalizations by ST elevation and type of intervention in the United States, 2001-2011. J. Am. Heart Assoc. 2015, 4, e001445. [CrossRef] [PubMed]

3. DeVon, H.A.; Hogan, N.; Ochs, A.L.; Shapiro, M. Time to treatment for acute coronary syndromes: The cost of indecision. J. Cardiovasc. Nurs. 2010, 25, 106-114. [CrossRef] [PubMed]

4. McNamara, R.L.; Wang, Y.; Herrin, J.; Curtis, J.P.; Bradley, E.H.; Magid, D.J.; Peterson, E.D.; Blaney, M.; Frederick, P.D.; Krumholz, H.M.; et al. Effect of door-to-balloon time on mortality in patients with ST-segment elevation myocardial infarction. J. Am. Coll. Cardiol. 2006, 47, 2180-2186. [CrossRef] [PubMed]

5. Body, R. Acute coronary syndromes diagnosis, version 2.0: Tomorrow's approach to diagnosing acute coronary syndromes? Turk. J. Emerg. Med. 2018, 18, 94-99. [CrossRef]

6. $\quad$ Birnbaum, Y.; Wilson, J.M.; Fiol, M.; de Luna, A.B.; Eskola, M.; Nikus, K. ECG diagnosis and classification of acute coronary syndromes. Ann. Noninvasive Electrocardiol. 2014, 19, 4-14. [CrossRef] [PubMed]

7. Willemsen, R.T.; Kietselaer, B.L.; Kusters, R.; Buntinx, F.; Dinant, G.J. Diagnostic tools for acute coronary syndrome (ACS): A challenge for general practitioners and cardiologists. Ned. Tijdschr. Geneeskd. 2014, 158, A8078.

8. Bozkurt, S.; Kaya, E.B.; Okutucu, S.; Aytemir, K.; Coskun, F.; Oto, A. The diagnostic and prognostic value of first hour glycogen phosphorylase isoenzyme BB level in acute coronary syndrome. Cardiol. J. 2011, 18, 496-502. [CrossRef]

9. Shah, A.S.V.; Anand, A.; Strachan, F.E.; Ferry, A.V.; Lee, K.K.; Chapman, A.R.; Sandeman, D.; Stables, C.L.; Adamson, P.D.; Andrews, J.P.M.; et al. High-sensitivity troponin in the evaluation of patients with suspected acute coronary syndrome: A stepped-wedge, cluster-randomised controlled trial. Lancet 2018, 392, 919-928. [CrossRef]

10. Jaffe, A.S.; Ordonez-Llanos, J. High-Sensitivity cardiac troponin: From theory to clinical practice. Rev. Esp. Cardiol. 2013, 66, 687-691. [CrossRef]

11. Liebetrau, C.; Nef, H.; Szardien, S.; Dörr, O.; Willmer, M.; Voss, S.; Troidl, C.; Hoffmann, J.; Rixe, J.; Rolf, A.; et al. Release kinetics of copeptin in patients undergoing transcoronary ablation of septal hypertrophy. Clin. Chem. 2013, 59, 566-569. [CrossRef] [PubMed]

12. Möckel, M.; Searle, J. Copeptin-marker of acute myocardial infarction. Curr. Atheroscler. Rep. 2014, 16, 421. [CrossRef] [PubMed]

13. Katan, M.; Christ-Crain, M. The stress hormone copeptin: A new prognostic biomarker in acute illness. Swiss Med. Wkly. 2010, 140, w13101. [CrossRef] [PubMed]

14. Yang, Y.; Gao, S.; Fang, Q.; Yang, J. Diagnostic value of copeptin combined with hypersensitive cardiac troponin T detection in early acute myocardial infarction: A prrotocol of randomized double-blind diagnostic trial. Medicine 2021, 100, e23949. [CrossRef]

15. Page, M.J.; McKenzie, J.E.; Bossuyt, P.M.; Boutron, I.; Hoffmann, T.C.; Mulrow, C.D.; Shamseer, L.; Tetzlaff, J.M.; Akl, E.A.; Brennan, S.E.; et al. The PRISMA 2020 statement: An updated guideline for reporting systematic reviews. J. Clin. Epidemiol. 2021, 134, 178-189. [CrossRef] [PubMed]

16. Hozo, S.P.; Djulbegovic, B.; Hozo, I. Estimating the mean and variance from the median, range, and the size of a sample. BMC Med. Res. Methodol. Springer 2005, 5, 13. [CrossRef]

17. Ades, A.E.; Lu, G.; Higgins, J.P.T. The interpretation of random-effects meta-analysis in decision models. Med. Decis. Mak. 2005, 25, 646-654. [CrossRef]

18. Egger, M.; Davey Smith, G.; Schneider, M.; Minder, C. Bias in meta-analysis detected by a simple, graphical test. BMJ 1997, 315, 629-634. [CrossRef]

19. Begg, C.B.; Mazumdar, M. Operating characteristics of a rank correlation test for publication bias. Biometrics 1994, 50, 1088-1101. [CrossRef]

20. Ahmed, T.A.N.; Johny, J.S.; Abdel-Malek, M.Y.; Fouad, D.A. The additive value of copeptin for early diagnosis and prognosis of acute coronary syndromes. Am. J. Emerg. Med. 2021, 50, 413-421. [CrossRef]

21. Alquézar, A.; Santaló, M.; Rizzi, M.; Gich, I.; Grau, M.; Sionis, A.; Ordóñez-Llanos, J.; Investigadores del Estudio TUSCA. Combined high-sensitivity copeptin and troponin T evaluation for the diagnosis of non-ST elevation acute coronary syndrome in the emergency department. Emergencias 2017, 29, 237-244. [PubMed]

22. Ay, M.O.; Erenler, A.K.; Dogan, T.; Yetim, M. Diagnostic value of copeptin in acute myocardial infarction. Eur. Rev. Med. Pharm. Sci. 2017, 21, 1576-1582.

23. Bahrmann, P.; Bahrmann, A.; Breithardt, O.A.; Daniel, W.G.; Christ, M.; Sieber, C.C.; Bertsch, T. Additional diagnostic and prognostic value of copeptin ultra-sensitive for diagnosis of non-ST-elevation myocardial infarction in older patients presenting to the emergency department. Clin. Chem. Lab. Med. 2013, 51, 1307-1319. [CrossRef] [PubMed]

24. Boeddinghaus, J.; Reichlin, T.; Nestelberger, T.; Twerenbold, R.; Meili, Y.; Wildi, K.; Hillinger, P.; Giménez, M.R.; Cupa, J.; Schumacher, L.; et al. Early diagnosis of acute myocardial infarction in patients with mild elevations of cardiac troponin. Clin. Res. Cardiol. 2017, 106, 457-467. [CrossRef] [PubMed]

25. Charpentier, S.; Maupas-Schwalm, F.; Cournot, M.; Elbaz, M.; Botella, J.M.; Lauque, D. Combination of copeptin and troponin assays to rapidly rule out non-ST elevation myocardial infarction in the emergency department. Acad. Emerg. Med. 2012, 19, 517-524. [CrossRef] 
26. Duchenne, J.; Mestres, S.; Dublanchet, N.; Combaret, N.; Marceau, G.; Caumon, L.; Dutoit, L.; Ughetto, S.; Motreff, P.; Sapin, V.; et al. Diagnostic accuracy of copeptin sensitivity and specificity in patients with suspected non-ST-elevation myocardial infarction with troponin I below the 99th centile at presentation. BMJ Open 2014, 4, e004449. [CrossRef]

27. Gaber, M.A.; Omar, O.H.M.; El-Deek, S.E.M.; Hassan, A.K.M.; Mahmoud, M.S.; Meki, A.M.A. Copeptin, miRNA-208, and miRNA-499 as New Biomarkers for Early Detection of Acute Coronary Syndrome. Appl. Biochem. Biotechnol. 2021. [CrossRef]

28. Hillinger, P.; Twerenbold, R.; Jaeger, C.; Wildi, K.; Reichlin, T.; Rubini Gimenez, M.; Engels, U.; Miró, O.; Boeddinghaus, J.; Puelacher, C.; et al. Optimizing Early Rule-Out Strategies for Acute Myocardial Infarction: Utility of 1-Hour Copeptin. Clin. Chem. 2015, 61, 1466-1474. [CrossRef]

29. Jacobs, L.H.J.; van Borren, M.; Gemen, E.; van Eck, M.; van Son, B.; Glatz, J.F.C.; Daniels, M.; Kusters, R. Rapidly rule out acute myocardial infarction by combining copeptin and heart-type fatty acid-binding protein with cardiac troponin. Ann. Clin. Biochem. 2015, 52, 550-561. [CrossRef]

30. Jeong, J.H.; Seo, Y.H.; Ahn, J.Y.; Kim, K.H.; Young Seo, J.; Chun, K.Y.; Lim, Y.S.; Park, P.W. Performance of Copeptin for Early Diagnosis of Acute Myocardial Infarction in an Emergency Department Setting. Ann. Lab. Med. 2020, 40, 7-14. [CrossRef]

31. Keller, T.; Tzikas, S.; Zeller, T.; Czyz, E.; Lillpopp, L.; Ojeda, F.M.; Roth, A.; Bickel, C.; Baldus, S.; Sinning, C.R.; et al. Copeptin improves early diagnosis of acute myocardial infarction. J. Am. Coll. Cardiol. 2010, 55, 2096-2106. [CrossRef]

32. Khan, S.Q.; Dhillon, O.S.; O’Brien, R.J.; Struck, J.; Quinn, P.A.; Morgenthaler, N.G.; Squire, I.B.; Davies, J.E.; Bergmann, A.; Ng, L.L. C-terminal provasopressin (copeptin) as a novel and prognostic marker in acute myocardial infarction: Leicester Acute Myocardial Infarction Peptide (LAMP) study. Circulation 2007, 115, 2103-2110. [CrossRef] [PubMed]

33. Kim, K.S.; Suh, G.J.; Song, S.H.; Jung, Y.S.; Kim, T.; Shin, S.M.; Kang, M.W.; Lee, M.S. Copeptin with high-sensitivity troponin at presentation is not inferior to seria.al troponin measurements for ruling out acute myocardial infarction. Clin. Exp. Emerg. Med. 2020, 7, 35-42. [CrossRef]

34. Lotze, U.; Lemm, H.; Heyer, A.; Müller, K. Combined determination of highly sensitive troponin T and copeptin for early exclusion of acute myocardial infarction: First experience in an emergency department of a general hospital. Vasc. Health Risk Manag. 2011, 7, 509-515. [CrossRef] [PubMed]

35. Maisel, A.; Mueller, C.; Neath, S.X.; Christenson, R.H.; Morgenthaler, N.G.; McCord, J.; Nowak, R.M.; Vilke, G.; Daniels, L.B.; Hollander, J.E.; et al. Copeptin helps in the early detection of patients with acute myocardial infarction: Primary results of the CHOPIN trial (Copeptin Helps in the early detection Of Patients with acute myocardial INfarction). J. Am. Coll. Cardiol. 2013, 62, 150-160. [CrossRef] [PubMed]

36. Mauermann, E.; Bolliger, D.; Seeberger, E.; Puelacher, C.; Corbiere, S.; Filipovic, M.; Seeberger, M.; Mueller, C.; Buse, G.L. Incremental Value of Preoperative Copeptin for Predicting Myocardial Injury. Anesth. Analg. 2016, 123, 1363-1371. [CrossRef]

37. Meune, C.; Zuily, S.; Wahbi, K.; Claessens, Y.E.; Weber, S.; Chenevier-Gobeaux, C. Combination of copeptin and high-sensitivity cardiac troponin T assay in unstable angina and non-ST-segment elevation myocardial infarction: A pilot study. Arch. Cardiovasc. Dis. 2011, 104, 4-10. [CrossRef]

38. Morawiec, B.; Przywara-Chowaniec, B.; Muzyk, P.; Opara, M.; Ho, L.; Tat, L.C.; Muller, O.; Nowalany-Kozielska, E.; Kawecki, D. Combined Use of High-Sensitive Cardiac Troponin, Copeptin, and the Modified HEART Score for Rapid Evaluation of Chest Pain Patients. Dis. Markers 2018, 2018, 9136971. [CrossRef]

39. Narayan, H.; Dhillon, O.S.; Quinn, P.A.; Struck, J.; Squire, I.B.; Davies, J.E.; Ng, L.L. C-terminal provasopressin (copeptin) as a prognostic marker after acute non-ST elevation myocardial infarction: Leicester Acute Myocardial Infarction Peptide II (LAMP II) study. Clin. Sci. 2011, 121, 79-89. [CrossRef]

40. Reichlin, T.; Hochholzer, W.; Stelzig, C.; Laule, K.; Freidank, H.; Morgenthaler, N.G.; Bergmann, A.; Potocki, M.; Noveanu, M.; Breidthardt, T.; et al. Incremental Value of Copeptin for Rapid Rule Out of Acute Myocardial Infarction. J. Am. Coll. Cardiol. 2009, 54, 60-68. [CrossRef]

41. Sebbane, M.; Lefebvre, S.; Kuster, N.; Jreige, R.; Jacques, E.; Badiou, S.; Dumont, R.; Cristol, J.P.; Dupuy, A.M. Early rule out of acute myocardial infarction in ED patients: Value of combined high-sensitivity cardiac troponin T and ultrasensitive copeptin assays at admission. Am. J. Emerg. Med. 2013, 31, 1302-1308. [CrossRef]

42. Slagman, A.; Searle, J.; Müller, C.; Möckel, M. Temporal Release Pattern of Copeptin and Troponin T in Patients with Suspected Acute Coronary Syndrome and Spontaneous Acute Myocardial Infarction. Clin. Chem. 2015, 61, 1273-1282. [CrossRef]

43. Smaradottir, M.I.; Ritsinger, V.; Gyberg, V.; Norhammar, A.; Näsman, P.; Mellbin, L.G. Copeptin in patients with acute myocardial infarction and newly detected glucose abnormalities-A marker of increased stress susceptibility? A report from the Glucose in Acute Myocardial Infarction cohort. Diab. Vasc. Dis. Res. 2017, 14, 69-76. [CrossRef] [PubMed]

44. Smaradottir, M.I.; Andersen, K.; Gudnason, V.; Näsman, P.; Rydén, L.; Mellbin, L.G. Copeptin is associated with mortality in elderly people. Eur. J. Clin. Investig. 2021, 51, e13516. [CrossRef] [PubMed]

45. Stallone, F.; Schoenenberger, A.W.; Puelacher, C.; Rubini Gimenez, M.; Walz, B.; Naduvilekoot Devasia, A.; Bergner, M.; Twerenbold, R.; Wildi, K.; Reichlin, T.; et al. Incremental value of copeptin in suspected acute myocardial infarction very early after symptom onset. Eur. Heart J. Acute Cardiovasc. Care 2016, 5, 407-415. [CrossRef]

46. Stengaard, C.; Sørensen, J.T.; Ladefoged, S.A.; Lassen, J.F.; Rasmussen, M.B.; Pedersen, C.K.; Ayer, A.; Bøtker, H.E.; Terkelsen, C.J.; Thygesen, K. The potential of optimizing prehospital triage of patients with suspected acute myocardial infarction using high-sensitivity cardiac troponin T and copeptin. Biomarkers 2017, 22, 351-360. [CrossRef] [PubMed] 
47. Möckel, M.; Searle, J.L.; Hamm, C.; Slagman, A.; Blankenberg, S.; Huber, K.; Katus, H.; Liebetrau, C.; Müller, C.; Muller, R.; et al. Early discharge using single cardiac troponin and copeptin testing in patients with suspected acute coronary syndrome (ACS): A randomized, controlled clinical process study. Eur. Heart J. 2015, 36, 369-376. [CrossRef]

48. Lu, J.; Wang, S.; He, G.; Wang, Y. Prognostic value of copeptin in patients with acute coronary syndrome: A systematic review and meta-analysis. PLoS ONE 2020, 15, e0238288. [CrossRef]

49. Mueller, M.; Beitzke, D.; Scherz, T.; Loewe, C.; Mangold, A.; Marculescu, R.; Poppe, M.; Sterz, F.; Herkner, H.; Lang, I.; et al. Copeptin Levels Are Independent from Mild Therapeutic Hypothermia but Do Not Predict Infarct Size in Patients Presenting with ST-Segment Elevation Myocardial Infarction. J. Cardiovasc. Dev. Dis. 2021, 8, 131. [CrossRef] [PubMed] 